\title{
Relationship between School Health Programme and Academic Performance of Primary School Pupils in Southwest Nigeria
}

\author{
Ajayi-Vincent O. B \& Alebiosu E. O \\ Dept. of Human Kinetics and Health Education Ekiti State University, Ado-Ekiti.
}

\begin{abstract}
School health services are preventive and curative services provided for learners and staff within the school setting to ensure healthy school community. This study examines school health services and academic performance of primary school pupils in southwest Nigeria. The study was a descriptive research. The population consisted of all health education teachers and all primary six pupils in Ekiti State. Multistaged, simple random sampling and purposive random sampling techniques were used to collect data. The data collected were analysed using descriptive and inferential statistics.

The study revealed that the level of school health services is moderate in southwest Nigeria and that the level of academic performance is high in southwest Nigeria. Based on the findings, stakeholders, community, agencies, nations and international organisations should join hands to improve the status of school health services in southwest Nigeria.
\end{abstract}

Keywords: School Community, preventive health, immunisation, communicable diseases.

\section{Introduction}

Health is an important factor in national development. It appears that the test of civilization in any nation depends on the measure of consideration and care which it gives to it citizenry. To wit that the quality of man's health is determined by the quality of health care services he receives. It follows therefore that healthy pupils make a healthy nation and only such a nation could be wealthy. School health services are essential component of effective school health programme which ensure that children are healthy and able to team at all times;

1. Asserted that school health services are essential health care based on practical, scientifically sound and socially acceptable health services provided by the physicians, dentists, school health nurses and promote the heath of members of the school community.

2. Asserted that school health services are economical and powerful means of raising community health. The school health service is a personal health service which has developed from the narrower concept of medical examination of children to the present day broadened concept of comprehensive care of the health and well-being of children throughout the school years.

3. Discovered that the objectives of school health service include the promotion of positive health prevention of diseases, early diagnosis, treatment and follow-up of defects and awakening of health consciousness in children among others.

4. Posited that prevention of communicable diseases through immunization is the most emphasised school health services function. Immunization is given against communicable diseases and the records of immunization are kept as part of the school health records. Measures of first aid and emergency are provided in the school for emergency care by trained teachers and school nurses. Adequate nutrition and mid-day meal services are provided for pupils for proper growth and mental development.

5. Posited that the major aim of school health is to provide learning opportunities, experiences, services and an environment that will favourably influence the values, attitudes, practices and cognitive capabilities of the school pupils.

6. Submitted that through adequate school health services, children as well as parents can be educated. It has the potentials for developing proper attitudes, habits and imparting scientific information.

\section{Hypothesis:}

1. There is no significant relationship between school health services academic performance of primary school pupils in southwest Nigeria.

2. There is no significant contribution of school services to academic performance of primary school pupils in southwest Nigeria. 


\section{Method}

The study adopted the descriptive survey research design. The estimated population for the study was 1006 primary school pupils from the sampled primary school in southwest Nigeria. The instrument used for data collection was a self-structured questionnaire which was validated by experts as the department of physical and health education, Ekiti State University, Ado-Ekiti in terms of face and content validity. The corrections and suggestions were incorporated into the final copy of the instrument. Test-retest of the instrument using Pearson Product Moment Correlation yielding a reliability co-efficient of $r=0.85$ which was considered adequate for the study. The questionnaire was administered with the assistance of two trained research assistance.

\section{Data analysis:}

The data collected were analysed using both descriptive and inferential statistics frequency counts, percentages, mean and standard deviation were used to analyse the general questions while Pearson Product Moment Correlation Coefficient and Regression analysis were used to test the hypothesis at 0.05 level of significance. The results showed that the level of school health services in southwest Nigeria is low while the level of academic performance was high.

\section{Result}

Table 1: Percentage Response on School Health Services

\begin{tabular}{|c|c|c|c|c|c|c|c|c|c|}
\hline S/ N & COMMENT & SA & $\% \mathrm{SA}$ & A & $\% \mathrm{~A}$ & $\mathrm{D}$ & $\% \mathrm{D}$ & SD & $\begin{array}{l}\% \\
\mathrm{SD}\end{array}$ \\
\hline 1. & $\begin{array}{l}\text { School health service deals with protecting and } \\
\text { promoting the health of pupils and staff. }\end{array}$ & 315 & 31.3 & 516 & 51.3 & 121 & 12.0 & 54 & 5.4 \\
\hline 2. & $\begin{array}{l}\text { The school undertakes health appraisal of pupils on } \\
\text { admission }\end{array}$ & 192 & 19.4 & 467 & 46.4 & 281 & 27.9 & 66 & 6.6 \\
\hline 3. & $\begin{array}{l}\text { Health inspection is routinely carried out in the } \\
\text { school }\end{array}$ & 212 & 21.1 & 538 & 53.5 & 196 & 19.5 & 60 & 6.0 \\
\hline 4. & $\begin{array}{l}\text { The school has adequate and qualitative first } \\
\text { Aid box }\end{array}$ & 230 & 22.9 & 494 & 49.1 & 203 & 20.2 & 79 & 7.9 \\
\hline 5. & The school has a functional health team. & 173 & 17.2 & 439 & 43.6 & 297 & 29.5 & 97 & 9.6 \\
\hline 6. & $\begin{array}{l}\text { Height and weight measurement of the students are } \\
\text { regularly carried out to monitor their growth rate } \\
\text { and development. }\end{array}$ & 145 & 14.4 & 398 & 39.6 & 302 & 30.0 & 161 & 16.0 \\
\hline 7. & $\begin{array}{l}\text { The school has facilities for prompt referral of } \\
\text { emergencies to the hospital }\end{array}$ & 131 & 13.0 & 398 & 39.6 & 314 & 31.2 & 163 & 16.2 \\
\hline 8. & $\begin{array}{l}\text { School health advisory councils build support for } \\
\text { school health programme. }\end{array}$ & 156 & 15.5 & 468 & 46.5 & 235 & 23.4 & 147 & 14.6 \\
\hline 9. & $\begin{array}{l}\text { The school has a link with non-government } \\
\text { organizations }\end{array}$ & 160 & 15.9 & 399 & 39.7 & 309 & 30.7 & 138 & 13.7 \\
\hline 10. & $\begin{array}{l}\text { Co-ordination of the overall health programme } \\
\text { of } 228 \text { the school is vested on the Headmaster }\end{array}$ & 22.7 & 406 & 40.4 & 246 & 24.5 & 126 & 12.5 & \\
\hline 11. & $\begin{array}{l}\text { The records of all immunizations are usually kept } \\
169 \text { in the school health record card of the school } \\
\text { pupils. }\end{array}$ & & 16.8 & 372 & 37.0 & 289 & 28.7 & 176 & 17.5 \\
\hline 12. & $\begin{array}{l}\text { There is a special clinic where dental, eye, ear, } \\
147 \text { nose and throat defects in the school children } \\
\text { are detected and corrected. }\end{array}$ & & 14.6 & 243 & 24.2 & 356 & 35.4 & 260 & 25.8 \\
\hline 13. & $\begin{array}{l}\text { Routine examination of urine and blood of school } \\
120 \text { pupils are done to detect any abnormality. }\end{array}$ & & 11.9 & 260 & 25.8 & 346 & 34.4 & 280 & 27.8 \\
\hline 14. & $\begin{array}{l}\text { Detected abnormalities are promptly corrected to } \\
\text { avoid major setbacks in life }\end{array}$ & 185 & 18.4 & 405 & 40.3 & 243 & 24.2 & 173 & 17.2 \\
\hline 15. & $\begin{array}{l}\text { Proper School Health Service will enhance sound } \\
\text { health and better academic performance of school } \\
\text { pupils }\end{array}$ & 391 & 38.9 & 443 & 44. & 90 & 8.9 & 82 & 8.2 \\
\hline & TOTAL & 2954 & 294 & 6246 & 621 & 3828 & 380.5 & 2062 & 205 \\
\hline & MEAN & 197 & 19.6 & 416 & 41.4 & 255 & 25.4 & 137 & 13.7 \\
\hline
\end{tabular}

Percentage Response on school health Services.

Table 1 revealed the level of school health services as computed in percentage 39.1 per cent had low level, 41.4 per cent had moderate level while 19.6 per cent had high level of school health services. This means that the various activities under school health services are moderate in southwest Nigeria.

Table 2: Level of school health services.

\begin{tabular}{|l|l|l|l|}
\hline & Range & Frequency & Percentage \\
\hline Low & $15.00-32.30$ & 145 & 14.4 \\
\hline Moderate & $32.31-47.75$ & 697 & 69.3 \\
\hline High & $47.76-60.00$ & 164 & 16.3 \\
\hline Total & & 1006 & 100.0 \\
\hline
\end{tabular}




\section{Hypothesis 3}

There is no significant relationship between school health services and academic performance of school pupils. Scores on school health services and academic performance of school pupils were obtained and subsequently subjected to statistical analysis involving Pearson Product Moment Correlation at 0.05 level. Result is shown in Table 22.

Table 3: Relationship between School Health Services and Academic Performance of School Pupils

\begin{tabular}{|l|r|l|r|r|r|}
\hline Variable & $\mathrm{N}$ & Mean & SD & Rcal & Rtable \\
\hline School health & 1006 & 2.67 & 0.52 & & $0.629^{*}$ \\
\hline services & & & & & \\
\hline $\begin{array}{l}\text { Academic } \\
\text { performance }\end{array}$ & 1006 & 1.86 & 0.03 & & \\
\hline${ }^{*} \mathrm{P}<0.05$ & & & & & \\
\hline
\end{tabular}

The result in Table 22 revealed that there is significant, high and positive relationship between school health services and academic performance of school pupils. rcalculated (0.629) is greater than rtable (0.195) at 0.05 level of significance. Therefore, the null hypothesis is rejected. It means there is significant relationship between school health services and academic performance of school pupils in Southwest Nigeria.

\section{Question 2: What is the Level of Academic Performance of School Pupil in Southwest Nigeria?}

In answering the question, results of primary six pupils in the placement examination into JSS1 for 2010-2012 were obtained from the state ministry of education examination and records department of the three states sampled in Southwest Nigeria (Ondo, Ekiti and Osun). The analysis of the result is presented in Table 19 and Figure 4.

Table 19: Percentage Score of Academic Performance of School Pupils in Southwest Nigeria

\begin{tabular}{|l|l|r|l|r|r|r|}
\hline YEAR & & PASS & & & FAIL \\
\hline & ENROLMENT & N & & $\%$ & N & $\%$ \\
\hline 2010 & 128530 & 114692 & 89.2 & 13838 & & 10.8 \\
\hline 2012 & 126023 & 109414 & 86.8 & 16609 & & 13.2 \\
\hline TOTAL & 127575 & 114341 & 89.6 & 13234 & & 10.4 \\
\hline
\end{tabular}

Source: State Ministry of Education, Examination and Record Department

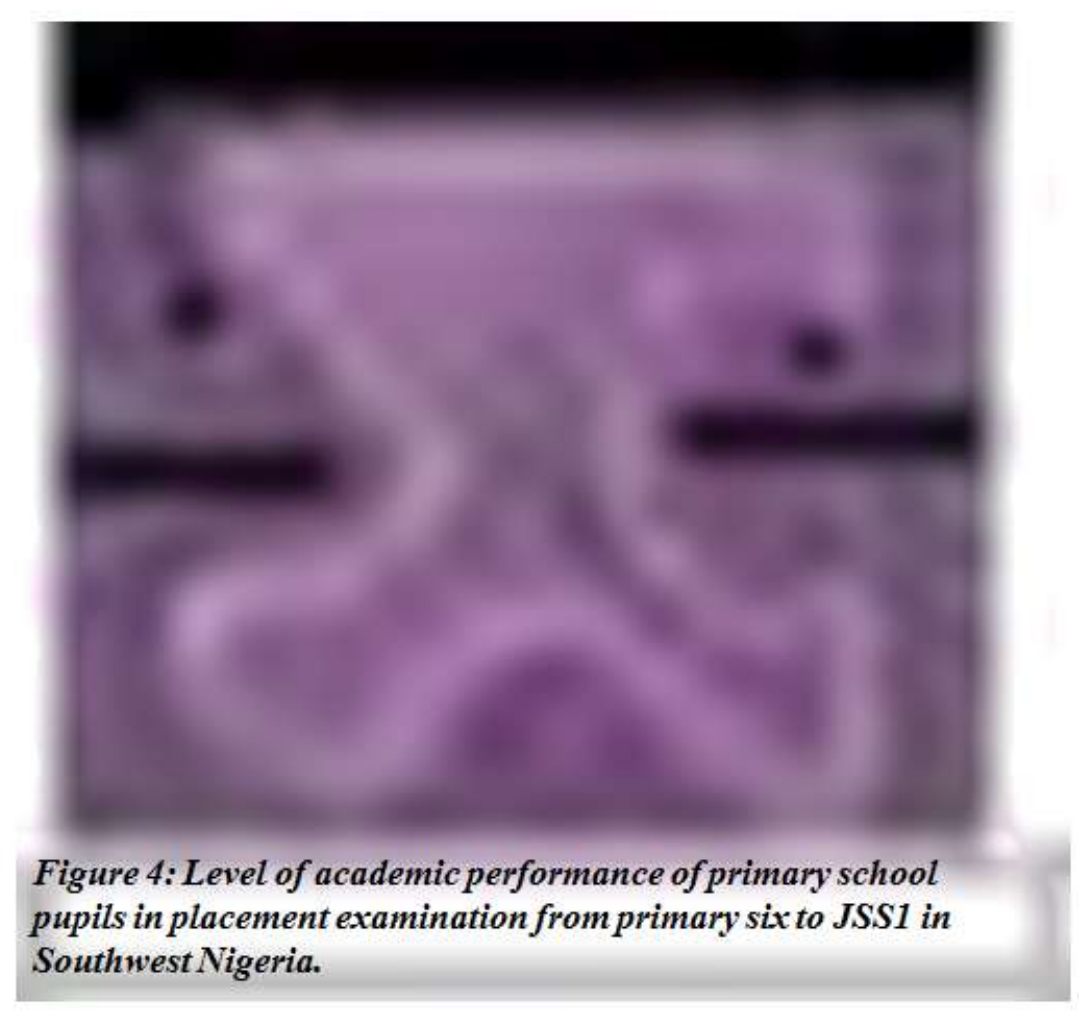


To determine the level of academic performance of primary school pupils in Southwest Nigeria. The result of placement examination from primary six to JSS1 were computed as shown in Table 19 and figure 4.

In year 2010 out of 128,530 pupils that sat for the placement examination from primary six to JSS1 114,692 passed showing a percentage of 89.2 while 13,838 failed showing a percentage of 10.8 .

Similarly in the year 2011,126023 primary six pupils enrolled while 109,414 passed to get 86.8 percent. 16609 of the pupils failed making 13.2 percent failure. Finally in year 2012, 127575 sat for the placement examination, 114,341 passed making a percentage of 89.6 percent. 13,234 pupils failed to make 10.4 percent failure.

The level of academic performance of the school pupils on the whole showed that 382,128 pupils sat for the placement examination between years 2010 to years 2012, 338,447 passed making a percentage of 88.6 while overall failure or absent was 11.4 percent. This showed that the level of academic performance of primary school pupils in the placement examination from primary six to JSS1 in Southwest Nigeria is high.

\section{Testing of Hypotheses}

The hypotheses generated in the study were tested using Pearson Product Moment Correlation and Regression analysis at 0.05 level of significance.

\section{Hypothesis 1}

There is no significant relationship between school health education and academic performance of school pupils.

In order to test the hypothesis, scores of academic performance of pupils in the placement examination from the sampled states were obtained and converted to weight scores. Similarly, scores relating to school health education were computed using the items in section B of the questionnaire. Scores on school health education and academic performance of school pupils were subjected to statistical analysis involving Pearson Product Moment Correlation at 0.05 level of significance.

The discussion of the general question 2 presented in Table 19 and Figure 4 revealed the result of placement examination of primary six pupils to JSS 1 from $2010-2012$. The result showed from the overall performance that 382, 128 (Three hundred and eighty two thousand, one hundred and twenty eight) pupils sat for the examination, 388,447 pupils passed, making a total of $88.6 \%$ pass while 43,681 pupils failed, making a percentage of $11.4 \%$ failure. This implied that the level of academic performance of school pupils in the Southwest Nigeria is high. This was supported by Okafor (2001) who discovered that where school health programme is well put in place, the academic performance of pupils would be enhanced.

\section{Discussion:}

The study revealed that the level of school health services in southwest Nigeria was moderate as discovered from the general questions raised. Findings from table 1 revealed that mean, standard deviation and percentages were used to categorise the level of school health serviced into "low", "moderate" and "high" based on response from the respondents on the questions on school health services using Likert's rating scale of preference to get the percentage response, the instruments were categorized into high, moderate and low as follows:

Reponses under strongly agree (SA) - high Reponses under agree (A) - moderate Responses under disagree (D) and strongly disagree were categorised as low based on the responses of respondents from the questions raised using Likert's scale of preference.

Table 2 showed findings from mean and standard deviation computations from school health services when categorized into low, moderate and high respectively. The result showed that the level of school health services in southwest Nigeria was moderate. When this findings is in line with Allensworth, D.D. \& Wilford C.A (2000) who discovered that school health services are preventive and curative services for the promotion of positive health status of school pupils and staff. Ajala, J.A. (2000) argued that the school health services which include all efforts of the school to conserve, protect and improve the health status of the school population are still suffering set-back in some aspects of southwest Nigeria, hence the moderate level discovered on the field.

Table 3 shows that there was no significant relationship between school health services and academic performance of primary school pupils in southwest Nigeria. This is as shown in table 3 where rcal (0.629) is greater than rtable (0.195) at 0.05 level of significance. The findings agreed with the view of Ajala, J.A. (2000) who discovered that school health services can reinforce the effort of the parents and the family physician in promoting the health and wellbeing of school pupils by providing learning opportunities, experiences, services and an environment that will favourably influence the values attitudes, practices and cognitive capabilities of school pupils. Supporting this view, the World Health Organisation (WHO), United Nation Children Emergency Fund (UNICEF) and United Nations Educational Scientific and Cultural Organisation (UNESCO) all made 
valuable efforts to support promoting the health of the school pupils and staff through effective school health services, thereby affecting their academic performance positively.

Table 4 showed that there were significant contributions of school health services to academic performance of school pupils as shown in table 4 figure1. It was discovered that school health services showed significant impact on pupils' academic performance. The findings of Marx, Wooley and Northrop who discovered that a comprehensive school health services is a well-planned sequential strategies, activities and services designed to promote the optimal physical, emotional, social and educational development of school pupils.

\section{Conclusion}

Based on the findings of this study, it would be concluded that the practice of school health services is moderate in southwest Nigeria and that academic performance of primary school pupils is high. Also, that school health services could significantly influence academic performance of primary school pupils, these are services provided for pupils to appraise, protect and promote health which in turn would enhance better academic performance. Considering the importance of this laudable programme, it was recommended that government, stakeholders, health educators, curriculum planners and school administrators should jointly advocate for effective practice if school health service in school to benefit both and school personnel.

\section{References}

[1]. Ademuwagun, Z.A \& Oduntan, S.O. (2003). A School Health Education Handbook, Ibadan: University Press Limited.

[2]. Ajala, J.A. (2000). Healthful Environment: A Strategy for Fostering Quality of Life. In J.A. Ajala Deflating the Inflation Monster: A Survival Kit for Healthful Living during scarcity; Ibadan: Department of Physical and Health Education, University of Ibadan Pg $33-39$.

[3]. Allensworth, D.D. \& Wilford C.A (2000). Schools as Agents for Achieving the 1990 Health Objectives for the Nation; Quarterly Health Education Journal, (15): 3 - 15.

[4]. Lucas, A.O. \& Gilles, H.M. (2003). Textbook of Public Health Medicine for the Tropics; London: Printed by Hodder Education.

[5]. Marx, E., Wooley, S.F. \& Northrop, D. (1998). Health in Academics: A Guide to Coordinated School Health Programs; New York: Teachers College Press.

[6]. Moronkola, O.A. (2003). Current Status, Challenges and Future of School Health Education in Nigeria. Journal of Educational Development 1 \&2: 11-19.

[7]. Okafor, J.O. (2001). A Functional Approach to School Health Education: Awka; Mekb Unique Publisher Nig. Ltd.

[8]. Park, K. (2007). Park Textbook of Preventive and Social Medicine; India: M/S Banarsidas Bhanot Publishers. 